\title{
CONSTANTINE AND THE LEGAL RECOGNITION OF CHRISTIANITY: WHAT CHANGED, AND SOME HISTORICAL FORERUNNERS
}

\begin{abstract}
"L'età di Costantino avviò il paganesimo a minoranza, non già limitandone la libertà, né ricorrendo alla repressione, bensì consentendo ai cristiani libertà di azione e privilegi di vario genere [...] [Costantino] volle dapprima equiparare le comunità cattoliche ai sodalizi religiosi pagani, per quanto riguardava l'esercizio di diritti; quindi le identificò, tramite iniziative del tutto personali, come soggetti favorevoli’”.
\end{abstract}

Putting Christian religion on a par with "pagan" cults - and Judaism, which was already a religio licita in the Empire - meant the acknowledgement of Christianity, too, as a religio licita in the Roman Empire. Now Lactantius describes this official recognition of Christianity in the Empire as the very first act of Constantine as an emperor:

"As soon as he took on the imperial power, Constantine Augustus did nothing before returning the Christians to their cult and their God. This was his first decision: the restoration of this holy religion"2.

Lactantius deploys the terminology of restoration (reddere, restitutae) with reference to Constantine's policy because - I surmise - he has in mind Gallien's recognition of Christianity in A.D. 262 or earlier. This made Christianity a religio licita in the Empire, but the Diocletian persecution subverted this principle, which was restored by Constantine. Without Gallien's precedent, it would have made no sense for Lactantius to speak of a restoration of Christianity,

* Ilaria L.E. Ramelli - Full Professor of Theology and Bishop Kevin Britt endowed Chair in Dogmatics - Christology at the Graduate School of Theology at Sacred Heart Major Seminary of the Thomas Aquinas University (Detroit), Senior Visiting Professor of Greek Thought, Church History, and Senior Research Fellow in Religion at Erfurt University, Senior Research Fellow in Ancient and Patristic Philosophy at Durham University, e-mail: ilaria.ramelli@unicatt.it.

${ }^{1}$ G. Rinaldi, Ridurre a minoranza. Riflessioni su alcuni percorsi dei pagani nell'impero dei cristiani, in: Cristianesimo e democrazia, ed. G. Otranto, Bari 2011, 142-143.

${ }^{2}$ Lactantius, De mortibus persecutorum 24, 9, ed. J. Moreau, SCh 39, Paris 1954, 106: "Suscepto imperio Constantinus Augustus nihil egit priusquam Christianos cultui ac Deo suo reddere. Haec fuit prima eius sanctio sanctae religionis restitutae", transl. by I.R. 
a religion that was against the law and enjoyed no official recognition in the Empire, but only, sometimes, tolerance or sympathy at best.

Thomas George Elliott ${ }^{3}$ has presented a Constantine who had become a Christian already during the persecutions under the Tetrarchs, which would perfectly fit Lactantius's above-quoted statement that Constantine "restored" Christianity as soon as he gained power. Constantine was not simply a political opportunist; "he was throughout his imperial career a man with a mission"" Harold Allen Drake, on the other hand, is unconcerned about the sincerity of Constantine's religious convictions in and after A.D. 312: "It is better to situate Constantine's religious development in the context of contemporary power politics and political thought" . For Constantine, acquiring the support of a Christian constituency was more consequential than accepting Christian beliefs. Raymond Van Dam downplays the reliability of Eusebius's account of Constantine's conversion at the Milvian Bridge in De vita Constantini ${ }^{6}$, not by denying that Eusebius's narrative is based on Constantine's memories, but by claiming that these memories had deformed over time ${ }^{7}$. Here we are rather concerned with the consequences that this "conversion" had on Constantine's religious legislation, which, as I have pointed out, Lactantius presents as Constantine's first political act as an emperor.

The other claim by Lactantius in Divinae institutiones refers to Constantine's own conversion to Christianity, which is not taken into consideration in the first passage (possibly because, as Timothy Barnes thinks, that passage refers to the year 306 and not to the year $313^{8}$ ):

"You were the first among the Roman emperors to repudiate errors and recognise and worship the majesty of the one, true God [...] when you restored justice, which had been turned upside down and suppressed, and thereby you expiated the most hideous crime of others"'.

The terminology of restoration returns here: Lactantius can say that Constantine restored or brought back justice, which had been suppressed beforehand (eversam sublatamque iustitiam reducens), only if he means that Constantine

${ }^{3}$ Cf. Th.G. Elliott, The Christianity of Constantine the Great, London 1996.

${ }^{4}$ Ibidem, p. 328.

${ }^{5}$ H.A. Drake, Constantine and the Bishops. The Politics of Intolerance, Baltimore 2000, 191. Cf. also M. Wallraff, Die Lage der Kirche unter Konstantin und seinen Nachfolgern, in: AthanasiusHandbuch, hrsg. P. Gemeinhardt, Tübingen 2011, 31-38.

${ }^{6}$ Cf. Eusebius Caesariensis, De vita Constantini I 27, 1 - 41, 2.

${ }^{7}$ Cf. R. Van Dam, Remembering Constantine at the Milvian Bridge, Cambridge 2011.

${ }^{8}$ Cf. T. Barnes, Lactantius and Constantine, in: Early Christianity and the Roman Empire, ed. T. Barnes, London 1984, 44.

${ }^{9}$ Lactantius, Divinae institutiones I 1, 13, ed. P. Monat, SCh 326, Paris 1986, 36: "Primus Romanorum principum, repudiatis erroribus, maiestatem Dei singularis ac veri et cognovisti et honorasti. [...] cum eversam sublatamque iustitiam reducens, taeterrimum aliorum facinus expiasti", transl. by I.R. 
restored the justice established by Gallien, with the official recognition of Christianity, and later subverted with the Diocletian persecution. In Lactantius's view, Constantine restored the right pre-Diocletian juridical status, that is to say, the juridical situation established by Gallien in which Christianity was a religio licita.

In this respect, a certain anticipation was provided by Galerius, with his edict of toleration issued in Nicomedia on 30 April of the year 311 in the name of himself, Maximinus, Constantine, and Licinius ${ }^{10}$. Likewise Licinius on 13 June published a letter to the governor of Bithynia with which he allowed the Christians and everyone else to follow any religion ${ }^{11}$. The lexicon of restoration used by Galerius in his edict is the same as I have pointed out in Lactantius for Constantine, and can only be explained with the juridical situation created by Gallien: if Galerius allows "Christians to exist again" (ut denuo sint Christiani), he clearly refers to the period between Gallien's edict and the Diocletian persecution during which - for the first time in the Roman Empire - it was legal to be a Christian, whereas before Gallien the principle was enforced that, "it is not permitted by the law to be Christians" (non licet esse vos [Christianos] $)^{12}$.

Gallien's edict is known only through Eusebius ${ }^{13}$, who reports a rescript to Dionysius of Alexandria and other Egyptian bishops, after Gallien had restored his power in those lands upon a usurpation. He says that he now extends to those territories, too, the benefits that the Christians already enjoyed in the rest of the empire under his reign. He returned churches and cemeteries - which had been confiscated - to the bishops, and gave to the latter a copy of his decision, that they might avail themselves of it without being bothered by anyone ${ }^{14}$. T. Barnes is right to emphasise that Gallien in A.D. 260 already recognised Christianity as a religio licita ${ }^{15}$.

If Gallien in fact made Christianity a religio licita after more than two centuries, thereby anticipating what Constantine did shortly later, one may wonder why the effect of Gallien's initiative was only temporary, while that of Constantine proved permanent. The reason for this is probably that Gallien was no Christian himself, nor were his immediate successors, whereas Constantine was, and all of his successors were as well, apart from Julian for a very short time. Constantine, though, who like his father seems to have been a sun-worshipper, postponed his own baptism for a long while, and in the socalled Edict of Milan famously spoke only of a "supreme divinity"; likewise on his arch in Rome he ascribed his victory to the "prompting of a divinity".

\footnotetext{
${ }^{10} \mathrm{Cf}$. ibidem I 1, 33-35, with the quotation of the edict.

${ }^{11}$ Cf. ibidem I 1, 48. See Eusebius Caesariensis, HE X 5.

${ }^{12}$ Lactantius De mortibus persecutorum 34, 4, SCh 39, 118, transl. by I.R.

${ }^{13}$ Cf. Eusebius Caesariensis, HE VII 13.

${ }^{14}$ Cf. M. Sordi, I cristiani e l'impero romano, Milan 2004', 156-159.

${ }^{15}$ Cf. T. Barnes, Early Christian Hagiography and Roman History, Tübingen 2010, 97-105.
} 
It will be his successors, and especially Theodosius, who will make the Roman Empire Christian. What Constantine properly did was to reverse the effects of a senatus consultum which I shall discuss in a moment and which in Constantine's time was almost three centuries old; this senatus consultum seems to be the most probable juridical basis for the persecutions of the Christians in the Roman empire. Constantine put an end to these persecutions by means of the legal recognition of Christianity.

Neither Constantine nor Gallien, however, seem to have been the first Roman emperors who harboured at least the intention to recognise Christianity from the juridical point of view. There are clues that they had some predecessors on this score, namely - from the most recent to the most ancient, Severus Alexander, Elagabalus, Hadrian, and Tiberius. Their attempts, unlike Constantine's legislative act, had no success; nevertheless it is important for the historian to analyse the sources concerning such attempts and to assess their reliability and their meaning.

According to the Historia Augusta, in the Severan age, Elagabalus and Severus Alexander wanted to legalise Christianity in the Empire. The nature and author or authors of the biographies that make up the Historia Augusta is notoriously debated. Nicomachus Flavianus was the author of the whole of the Historia Augusta in the years 392-394 according to Stéphane Ratti ${ }^{16}$, but there is no unanimity in scholarship on this point. The reliability of each single piece of information must be vetted, but this document too is worth studying, all the more so in the light of Christian traces that have been detected in the Historia Augusta ${ }^{17}$.

In Vita Elagabali it is reported that Elagabalus, as soon as he arrived at Rome in the year 219, had a temple built on Mount Palatine, close to the imperial residence ${ }^{18}$. His intention was to transfer into that temple all the deities that were object of worship for the Romans, as well as the cults of the Jews, the Samaritans and the Christians ${ }^{19}$. According to this report, Elagabalus wanted to integrate Christianity into the main religions of the Empire, along with "pagan" cults, Judaism, and the Samaritan religion, considered as separate from Judaism. In the light of Elagabalus's syncretistic tendencies, and of what I am going to argue in a moment, this account is likely to have some historical grounds.

According to the same source, indeed, Severus Alexander in his lararium on Mount Palatine worshipped together, in a syncretistic fashion, Christ, Abraham, Orpheus, and Apollonius of Tyana ${ }^{20}$. He wished, like Hadrian before

\footnotetext{
${ }^{16}$ Cf. S. Ratti, Polémiques entre païens et chrétiens, Paris 2012.

${ }^{17}$ See F. Mundt, Die Maske des Christen - Spuren christlicher Literatur in der Historia Augusta, in: Es hat sich viel ereignet, Gutes wie Böses. Lateinische Geschichtsschreibung der Spät- und Nachantike, hrsg. G. Thome - J. Holzhausen - S. Anzinger, München 2001, 37-56.

${ }^{18}$ Cf. Scriptores Historiae Augustae. Vita Elagabali 3, 4-5.

${ }^{19}$ Cf. ibidem 3, 4-5.

${ }^{20}$ Cf. Scriptores Historiae Augustae. Vita Alexandri Severi 22, 4.
} 
him, to have a temple dedicated to Christ and to receive him among the gods ${ }^{21}$. This meant the legal recognition of Christianity in the Empire. Alexander, however, was prevented from pursuing this project by people who, consulting a sacrifice, found out that, if he had recognised Christianity as a legal religion, all people would become Christians and the "pagan" temples would be abandoned ${ }^{22}$. These unnamed priests, who consulted and interpreted a sacrifice that turned out to be against the emperor's project, were probably haruspices, experts in the Etrusca disciplina; the legal recognition of Christianity was not in their best interest, all the more so in that famous contemporary Christian intellectuals, such as Origen, overtly criticised haruspicy. Alexander esteemed the haruspices and accepted their advice, which resembles that of privileging haruspicy and traditional divination over and against foreign cults, which Cassius Dio probably intended to give to the same emperor in Maecenas' speech to Augustus ${ }^{23}$. Likewise, when Alexander wanted to open a new atrium in the imperial palace, according to a project that had been already devised by Septimius Severus, the haruspices prevented him to do $\mathrm{so}^{24}$. Alexander yielded to the haruspices' threatening advice not only out of his respect for the Etrusca disciplina, but probably due to the anxiety that - especially after Elagabalus's tragic end - the Senate arose in him. For the Senate was a stronghold of religious traditionalism, and the Etruscan component in it was not insignificant. In the Historia Augusta Alexander is presented as an ideal sovereign from the Senate's viewpoint. This source ascribes to him some reforms that aimed at restoring the Senate's power. In the Severan age the Senate included many members of Etruscan ancestry who were proud of their origin and favoured the order of the haruspices. Some even belonged to that order. In the third century A.D. the collaboration between haruspices and Senate was close; the former constantly backed the latter even when some emperors showed hostility to the Senate ${ }^{25}$. Thus, due to the influence of the haruspices and to the threat that senatorial hostility represented, Alexander ended up not

${ }^{21}$ Cf. ibidem $43,7$.

${ }^{22} \mathrm{Cf}$. ibidem $43,7$.

${ }^{23}$ Cf. Cassius Dio, Historiae Romanae 52, 36. See I. Ramelli, Cultura e religione etrusca nel mondo romano. La cultura etrusca alla fine dell'indipendenza, Alessandria 2003, Ch. 4.

${ }^{24}$ Cf. Scriptores Historiae Augustae. Vita Septimii Severi 24, 3.

${ }^{25}$ Another meaningful coincidence can be observed between the flourishing of Etruscan families in the Senate and the flourishing of haruspicy (cf. Ramelli, Cultura e religione etrusca, Ch. 4 and Appendix 1). Here the problems of the authorship and dating of the Historia Augusta need not detain us. Usually, even if not universally, it is deemed to have been composed by a single author between the fourth and the fifth centuries. See, e.g. D. Pausch, Libellus non tam diserte quam fideliter scriptus: Unreliable Narration in the Historia Augusta, "Ancient Narrative" 8 (2010) 115-135; R. Syme, Ammianus and the Historia Augusta, Oxford 1968; idem, Emperors and Biographies, Oxford 1971; T. Barnes, The Sources of the Historia Augusta, Bruxelles 1978; R. Syme, Historia Augusta Papers, Oxford 1983; the Historiae Augustae Colloquia. Nova series, ed. G. Bonamente et alii, Bari 1991-, and A. Cameron, The Last Pagans of Rome, Oxford 2011. 
legalising Christianity; neither did he persecute the Christians, though. Indeed, his reign closed a long epoch of "tolleranza di fatto" 26 or actual tolerance.

But is it likely that Alexander, in addition to abstaining from persecution, really intended to recognise Christianity de iure as well? I think so. Just as Eusebius, a faithful follower of Origen, was the intellectual inspirer of Constantine, who definitively legalised Christianity, so could Origen himself have been the inspirer of Alexander's initiative to legalise Christianity. And he could have inspired Alexander through the latter's mother, the empress Julia Mamaea, with whom Origen had long theological conversations. Eusebius himself attests with satisfaction that Julia was deeply interested in Origen as a Christian intellectual and "deemed it very important to be honoured by the visit of this man" 27 . Therefore, while she was in Antioch, she invited him, sending him an armed escort to accompany him to the place where she was staying; there they conversed for a long time. Also in the light of the influence of the Severan empresses on their sons and relatives, I suspect that Alexander's apparently odd decision to legalise Christianity may have been influenced to some extent by Julia's profound esteem for Origen. Indeed, it is precisely to speak of theology that she invited him - in Eusebius's words, to "have an experience of his un-

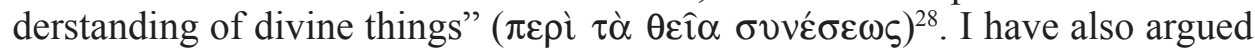
elsewhere that Eusebius, precisely in that he was the intellectual inspirer of Constantine, might have influenced the introduction of the homoousios formula in the Nicene Creed. This addition, as Eusebius attests in his letter to his own church, was formally proposed by the emperor. If Constantine was inspired by Eusebius, the latter was simply following Origen ${ }^{29}$.

The Historia Augusta suggests that Hadrian, too, may have been inclined to recognise Christianity:

"Severus Alexander wanted to make a temple for Christ and to receive him among the deities. Hadrian too, according to tradition, had this intention. He had ordered the construction of temples without images in all cities. Nowadays, too, these temples, which he was said to have had built for this reason, having no specific deities are called «temples of Hadrian»" ${ }^{" 30}$.

\footnotetext{
${ }^{26}$ So M. Sordi, I Cristiani e l'Impero Romano, Milan 1983, 87-103.

${ }^{27} \mathrm{Cf}$. Eusebius Caesariensis, HE VI 21, 3-4.

${ }^{28}$ Ibidem VI 21, 3-4, ed. and transl. K. Lake - J.E.L. Oulton: Eusebius, The Ecclesiastical History, vol. 1, Cambridge - London 1953, 67-68.

${ }^{29} \mathrm{Cf}$. I. Ramelli, Origen's Anti-Subordinationism and Its Heritage in the Nicene and Cappadocian Line, VigCh 65 (2011) 21-49.

${ }^{30}$ Scriptores Historiae Augustae. Vita Alexandri Severi 43, 6-7, ed. H. Hohl: Scriptores Historiae Augustae, vol. 1, Stutgardiae - Lipsiae 1997, 285: "Christo templum facere voluit [sc. Alexander Severus] eumque inter deos recipere. Quod et Hadrianus cogitasse fertur, qui templa in omnibus civitatibus sine simulacris iusserat fieri, quae hodieque, idcirco quia non habent numina, dicuntur Hadriani, quae ille ad hoc parasse dicebatur", transl. by I.R.
} 
This passage might result from a pro-Christian interpretation of Hadrian's rescript to Minucius (or Minicius) Fundanus in the years 124-125 $5^{31}$. Some scholars rejected the historicity of the Historia Augusta passage outright ${ }^{32}$. However, as has been remarked by Marco Rizzi ${ }^{33}$, a debate on cult without images was going on in the second century and involved the Middle Platonist Plutarch $^{34}$ and Lucian ${ }^{35}$. The former ascribed such a cult to the original Roman worship, and the latter to the original Egyptian religion. This is why Rizzi finds Hadrian's interest in Christianity and Judaism - qua cults without images - "not unlikely"36. Indeed, as for Judaism, in Genesis Rabba, which according to Jacob Neusner was composed in the fourth century ${ }^{37}$, a tradition is reported that in the time of rabbi Joshua ben Hananiah the State ordered that the Temple be built again ${ }^{38}$. This would have been, notably, another temple without images. At this point some "Samaritans" are said to have warned Hadrian that after the reconstruction of the Temple and of Jerusalem the Jews would have paid no tribute any longer. So the project was cancelled. The Roman emperor in this passage is unnamed, but the identification is easily made possible by the mention of rabbi Joshua ben Hananiah, who is repeatedly associated with Hadrian in the Mishnah. A similar hint can be found in the second-century Epistle of Barnabas, which, in reference to the Temple destroyed by the Romans in the year 70, states: "and now they will rebuild it, as slaves of the enemies" 39 . Here "they" probably refers to the Jews, who are said to be slaves of the Romans, their enemies, probably because of their condition of political subjugation, all the more so after the war narrated by Josephus in his Bellum Iudaicum (moreover, after that war, just as after the Bar Kochba war, large numbers of Jews were sold into slavery by the Romans). It is noteworthy that in the aforementioned passage from Genesis Rabba, too, the Jews are supposed to rebuild the Temple themselves, by order of the Romans, and with their consent.

${ }^{31}$ On which see my Nuove osservazioni per lo studio del rescritto di Adriano sui Cristiani, "Aevum" 81 (2008) 137-148.

${ }^{32} \mathrm{Cf}$. W. Schmid, Bilderlose Kult und christliche Intoleranz. Wesen und Herkunft zweier Nachrichten bei Aelius Lampridius (Alex. 43, 6f.), in: Mullus. Festschrift Theodor Klauser, hrsg. A. Stuiber, Münster 1964, 298-315; S. Angiolani, Severo Alessandro e i Cristiani nell'Historia Augusta, "Annali della Facoltà di Lettere dell'Università di Macerata" 27 (1994) 23-25.

${ }^{33}$ Cf. M. Rizzi, Hadrian and the Christians, in: Hadrian and the Christians, ed. M. Rizzi, Berlin 2010, 14-15.

${ }^{34}$ Cf. Lucius Mestrius Plutarchus, Numa 8.

${ }^{35}$ Cf. Lucianus Samosatensis, De dea Syra 2-3.

${ }^{36}$ Rizzi, Hadrian and the Christians, p. 15.

${ }^{37}$ Cf. J. Neusner, Judaism and Christianity in the Age of Constantine, Chicago 1987. There are, however, traces of earlier traditions in it, as for instance a comparison with Bardaisan of Edessa († 222) suggests. See I.L.E. Ramelli, Philo as Origen's Declared Model: Allegorical and Historical Exegesis of Scripture, "Studies in Christian-Jewish Relations" 7 (2012) 1-17.

${ }^{38}$ Cf. Genesis Rabba 64, 8.

${ }^{39}$ Barnabae Epistula 16, 4, ed. J. Henderson: The Apostolic Fathers, vol. 2, Cambridge - Lon-

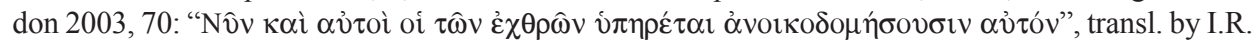


This intention of Hadrian, if it ever existed, of having the Jerusalem Temple rebuilt, disappeared with the Bar Kochba Messianic revolt of the years 132-135. After the end of what was actually a war, not inferior to the Jewish war that had culminated in the destruction of the Temple in the year 70, Hadrian, far from having the Temple rebuilt, had rather Jerusalem reconstructed as a Roman colony, forbidden to the Jews, and named Aelia in honour of himself, Aelius Hadrianus ${ }^{40}$, and Judea transformed into the province of Syria-Palestine. It is to be noticed that, while the followers of Bar Kochba were supported by other non-Jewish peoples ${ }^{41}$, the Christians kept their loyalty to Hadrian and probably for this reason were rather persecuted by the insurgents. This is confirmed both by Justin, who reports that:

"in the Jewish war which has occurred just now Bar Kochba, the leader of the revolt of the Jews, ordered only Christians to be dragged to terrible punishments unless they denied Jesus as Messiah and blasphemed against him"'t2,

and by a letter of Bar Kochba himself, who indicates the Christians as possibly hostile to the revolt ${ }^{43}$. Later on, Eusebius quoted Justin's account ${ }^{44}$ and Jerome insisted that "Bar Kochba, the leader of the Jewish faction, had Christians killed with all sorts of torments, because they did not want to contribute to the revolt against the Roman troops"45; the same piece of information is repeated by Orosius ${ }^{46}$. Justin stresses more the religious aspect, Jerome the political one, but these are obviously interrelated. Indeed, the Christians could not have Bar Kochba as their Messiah, since they had Jesus instead, and moreover chose to keep faithful to Hadrian. Likewise during the war that culminated with the destruction of the Temple in the year 70 the Christians who were in Jerusalem did not back the anti-Roman rebels, but fled to Pella ${ }^{47}$. The emperor Hadrian was also the addressee of at least two Christian apologies, by Aristides and Quadratus, delivered before the Jewish war.

${ }^{40}$ Cf. Eusebius Caesariensis, HE IV 6, 4.

${ }^{41}$ Cf. Cassius Dio, Historiae Romanae 69, 13, 2.

${ }^{42}$ Justinus Martyr, Apologia I31, 6, ed. G. Girgenti: Giustino, Apologie, testo greco a fronte, Mi-

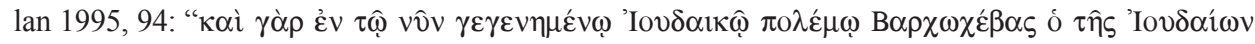

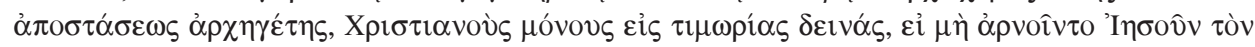

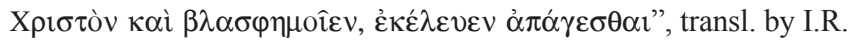

${ }^{43}$ Cf. P. Benoit - J.T. Milik - R. De Vaux, Discoveries in the Judaean Desert, II, Oxford 1961, 159-160. On Bar Kochba's letters and other findings see W. Cockle - H. Cotton - F. Millar, The Papyrology of the Roman Near East: A Survey, JRS 85 (1995) 214-235.

${ }^{44} \mathrm{Cf}$. Eusebius Caesariensis, HE IV 8, 4.

${ }^{45}$ Hieronymus, Chronicon sub anno 133 (Romanorum CCXXVIII Olymp.), ed. R.W.O. Helm, GCS 47 (Eusebius Werke 7/1), Berlin 1956, 201: "Cochebas, dux Iudaicae factionis, nolentes sibi Christianos adversum Romanum militem ferre subsidium omnimodis cruciatibus necat", transl. by I.R.

${ }^{46} \mathrm{Cf}$. Orosius, Historiae VII 13, 4.

${ }^{47} \mathrm{Cf}$. Eusebius Caesariensis, HE III 5, 3. Critical discussion in my The Jesus Movement's Flight to Pella and the 'Parting of the Ways', “Augustinianum" 54 (2014) 37-53. 
But it is to the age of Tiberius that, according to some sources which I am going to analyse, the first imperial attempt to recognise Christianity - and at the same time the first juridical basis for the persecution of the Christians must be dated. The legal basis for anti-Christian persecutions in the Roman Empire is debated among scholars and has been debated for a long time ${ }^{48}$. T. Barnes, for instance, thought that the basis of Roman law was the mos maiorum, and what Christianity was perceived to threaten was precisely the mos maiorum $^{49}$. He does not think that there was a specific pronouncement either of the Senate or of the Emperor. However, there are reasons to suppose that the anti-Christian legislation in the Empire was originally due to the Senate and stems from the age of Tiberius ${ }^{50}$, but the imperial power did not exploit the effects of the Senate's decision until Nero. Indeed, under Tiberius, Caligula, and Claudius, and under Nero before his U-turn in the year 62, Christians were never condemned as such by any Roman authority ${ }^{51}$.

In the year 35 Tiberius proposed to the Senate to recognise the Christian sect as a licit religion. The Senate refused to do so; as a consequence, Christianity turned out to be a superstitio illicita or "illegal superstition" in the Empire and the Christians were liable to death. Tiberius, however, did not change his mind and prevented accusations against the Christians by threatening their accusers with death (and indeed the senatus consultum remained ineffective until the year 62). So Tertullian in Apologeticum says:

"Tiberius, under whose reign the Christian name entered the world, received a report from Syria Palestine about what had revealed there the truth of the divinity itself. Then he reported this in turn to the Senate with the favour of his own imperial vote. The Senate, however, since it had not verified the matter personally, rejected this proposal. But the emperor remained of his opinion and threatened the accusers of the Christians with death penalty. Please consult your historical documents: there you will find that Nero was the first to cruelly use the imperial sword against this sect, which at that time was growing especially in Rome"s2.

${ }^{48}$ See already A.N. Sherwin-White, The Early Persecutions and Roman Law Again, JTS 3 (1952) 199ff.; A. Wlosok, Die Rechtsgrundlagen der Christenverfolgungen der ersten zwei Jahrhunderte, "Gymnasium" 66 (1959) 14ff.; G.E.M. de Ste Croix, Why Were the Early Christians Persecuted?, "Past and Present" 26 (1963) 6ff.

${ }^{49} \mathrm{Cf}$. T. Barnes, Legislation against the Christians, JRS 58 (1968) 32-50.

${ }^{50}$ Cf. I. Ramelli, Il senatoconsulto del 35 contro i cristiani, “Aevum” 78 (2004) 59-67; eadem, Possible Historical Traces in the Doctrina Addai?, Piscataway 2009.

${ }^{51}$ Cf. eadem, I romanzi antichi e il Cristianesimo. Contesto e contatti, Madrid 2001, 165-168.

${ }^{52}$ Tertullianus, Apologeticum 5, 2, ed. M. A. Carpin: Tertulliano, Difesa del Cristianesimo. Apologeticum, Rome - Bologna 2008, 138: "Tiberius ergo, cuius tempore nomen Christianum in saeculum introivit, adnuntiatum sibi ex Syria Palaestina quod illic veritatem ipsius divinitatis revelaverat, detulit ad Senatum cum praerogativa suffragii sui. Senatus, quia non ipse probaverat, respuit; Caesar in sententia mansit, comminans periculum accusatoribus Christianorum. Consulite commentarios 
The denomination Syria Palaestina comes from Tertullian's own time, being posterior to the Bar Kochba revolt. In the time of Jesus and Tiberius it was $I u$ daea. The reliability of Tertullian's passage was accepted by a scanty minority of historians ${ }^{53}$. Tertullian, though, would have had no advantage in inventing that the Senate, the most prestigious political order of Rome, outlawed Christianity if this was not the case. Moreover, his addressees, ,the leaders of the Roman Empire" (Romani imperii antistites), could check the acts of the Senate under Tiberius and give him the lie. Tertullian's report corresponds to Tiberius's politics of using ,astute reflection" ${ }^{54}$. If he was informed that the Jewish followers of Jesus were not against Rome, he had all the interest in recognising their religion as licit in the Empire, for the sake of an alliance in the delicate situation of the Near East. Indeed, when the Senate refused to admit the followers of Jesus as members of a licit religion (religio licita) in the Empire, Tiberius, by means of his legatus Lucius Vitellius, in the years 36-37 deposed those responsible for the condemnation of Jesus, Caiaphas and Pilate, as is attested by Josephus ${ }^{55}$. Precisely Vitellius's memories (commentarii $)^{56}$ may have been the source of Tertullian's report on the senatus consultum of the year 35 .

The information provided by Tertullian perfectly corresponds to the historical situation of the Julio-Claudian age, when it was indeed up to the Senate to decide whether to receive new deities ${ }^{57}$. In the age of Tiberius the Senate was the organ responsible for religious decisions, as a recent investigation by Szusza Várhely has confirmed ${ }^{58}$. Religious honours, temple buildings,

vestros: illic reperietis primum Neronem in hanc sectam cum maxime Romae orientem Caesariano gladio ferocisse", transl. by I.R.

${ }^{53}$ Namely, E. Volterra, Di una decisione del Senato romano ricordata da Tertulliano, in: Scritti in onore di Contardo Ferrini pubblicati in occasione della sua beatificazione, vol. 1, Milano 1947, 471ff.; C. Cecchelli, Un tentato riconoscimento imperiale del Cristo, in: Studi in onore di Aristide Calderini e Roberto Paribeni, vol. 1, Milano 1956, 351ff.; M. Sordi, I primi rapporti tra lo Stato romano e il Cristianesimo, "Rendiconti dell'Accademia dei Lincei" 12 (1957) 58-93; eadem, L'apologia del martire Apollonio, "Rivista di Storia della Chiesa in Italia" 18 (1964) 169-188; W.H.C. Frend, The Church and the Roman Empire, "Classical Review" 17 (1967) 196.

${ }^{54}$ Tacitus, Annales 6, 32, ed. C. Questa - B. Ceva: Publio Cornelio Tacito, Annali, Milan 19904, 406: "consiliis et astu", transl. by I.R. Cf. also Svetonius, De vita Caesarum. Tiberius 37, ed. F. Dessì: Caio Svetonio Tranquillo, Vite dei Cesari, vol. 1, Milan 198933, 354: "hostiles motus nulla postea expeditione suscepta per legatos compescuit [...] reges infestos suspectosque comminationibus magis et querelis quam vi repressit", transl. by I.R. See B. Levick, Tiberius the politician, London 1976.

${ }^{55}$ Cf. Josephus Flavius, Antiquitates Judaicae 18, 89-90 and 122. On Vitellius cf. also C.P. Thiede, Jesus und Tiberius. Zwei Söhne Gottes, München 2004, 199, 214, 230, 309-311 and 333.

${ }^{56} \mathrm{Cf}$. A. Galimberti, I commentarii di Lucio Vitellio e la fonte romana del XVIII libro delle Antichità Giudaiche di Flavio Giuseppe, "Historia" 48 (1999) 224-234.

${ }^{57}$ Cf. A. Giovannini, Tacite, l'incendium Neronis et les chrétiens, REA 30 (1984) 3-34. Tacitus (Annales 3, 60-64) attests that Tiberius left authority to the Senate in religious matters. See M.T. Griffin, The Senate's Story, JRS 87 (1997) 249-253.

${ }^{58}$ Cf. S. Várhely, The Religion of Senators in the Roman Empire. Power and Beyond, Cambridge 2011, 48-49. 
supplications, and the like had to be authorised by the Senate ${ }^{59}$. Quintilian clearly attests that religious matters were discussed in the Senate, as their supreme venue, until the end of the first century A.D., according to him, the most important decisions concerning augurs, responses, and all matters of religion were frequently discussed in the Senate ${ }^{60}$. Indeed, religion was the main area in which the Senate maintained its authority ${ }^{61}$. Specifically speaking of Tiberius, Tacitus in Annales remarks that in matters of religion the emperor wanted to leave to the Senate at least "a shade of its ancient authority" 62 . This is why he wanted the Senate to decide, for instance, about provincial temples. Tiberius denied official cult for himself in the provinces ${ }^{63}$.

Suetonius remarks on Tiberius's deference to the Senate ${ }^{64}$ and he states that Tiberius used to submit any question to the Senate ${ }^{65}$. However, he also notes that „he annulled some of the decisions of the Senate" (et constitutiones Senatus quasdam rescidit ${ }^{66}$. One of these rare cases took place in A.D. 35. It is very significant that, just three years before the senatus consultum of the year 35 of which Tertullian speaks, in the year 32 another senatus consultum took place about the admission of a new volume into the Sibylline books ${ }^{67}$. In the year 35, very similarly, a senatus consultum took place about the admission of a new religion into the cults recognised by the Romans. Unlike three years later, in the year 32 the Senate voted in favour of the admission, and Tiberius sent a letter with which he referred the issue to the quindecemviri sacris faciundis. Three years later he intervened as well, but against the decision of the Senate. Tiberius did not formally abrogate the senatus consultum, but he prevented its effects by means of his veto.

Tertullian's implication that a senatus consultum outlawed Christianity is confirmed by the Acts of Apollonius, a senator who died as a martyr under Commodus ${ }^{68}$, and above all by a Porphyrian passage. In the Acta martyris Apollonii, preserved in both Greek and Armenian, the praetorian prefect Tigidius Perennis (A.D. 180-182/185) refers to a senatus consultum, which outlawed the Christians qua tales: "The senatus consultum established that

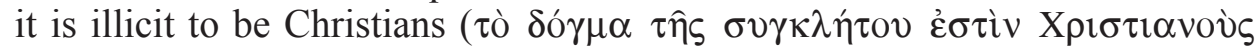

${ }^{59}$ Cf. R. Talbert, The Senate of Imperial Rome, Princeton 1984, note K.

${ }^{60} \mathrm{Cf}$. Quintilianus, Institutio oratoria XII 2, 21.

${ }^{61}$ Cf. Talbert, The Senate, p. 391.

${ }^{62}$ Tacitus, Annales 3, 60, ed. Questa - Ceva, p. 252: "imago antiquitatis", transl. by I.R.

${ }^{63}$ Cf. ibidem 4, 37-38; Supplementum Epigraphicum Graecum, vol. 11, ed. J.J.E. Hondius, Leiden 1954, 922-923. See D.S. Levene, Defining the Divine in Rome, "Transactions and Proceedings of the American Philological Association" 142 (2012) 41-81, esp. 76-77.

${ }^{64} \mathrm{Cf}$. Suetonius, De vita Caesarum. Tiberius 29.

${ }^{65} \mathrm{Cf}$. ibidem 30.

${ }^{66}$ Ibidem 33, ed. Dessì, p. 352, transl. by I.R.

${ }^{67} \mathrm{Cf}$. Tacitus, Annales 6, 12.

${ }^{68}$ Cf. Sordi, L'apologia del martire Apollonio, p. 169-188; V. Saxer, Martyrium Apollonii Romani, "Rendiconti della Pontificia Accademia di Archeologia" 55-56 (1982-1984) 265-298. 


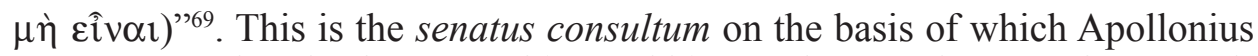
was sentenced to death, as Eusebius and his translator Rufinus confirm: Apollonius "was beheaded on the basis of the / a senatus consultum": $\alpha \pi$ ò $\delta$ ó $\gamma$ $\mu \alpha \tau o \varsigma \sigma v \gamma \kappa \lambda \eta \tau^{\prime} \sigma v^{70}$, secundum senatus consultum capite plexus est ${ }^{71}$. This corresponds to the senatus consultum that took place under Tiberius and made Christianity a superstitio illicita.

That a Porphyrian fragment, too, clearly refers to the same senatus consultum from the year 35 was argued by me in $2004^{72}$. The fragment at stake is reported by Macarius of Magnesia in Apocriticus $^{73}$ and was included by von Harnack as fr. $64^{74}$ in his collection of the fragments of Porphyry's work against the Christians, which stems from the Sixties or Seventies of the third century, or possibly somewhat later. Whether this passage is by Porphyry himself or by an anti-Christian polemicist who was inspired by Porphyry ${ }^{75}$, it certainly refers to the age of Tiberius, and more specifically to the years after Jesus's resurrection (around the year 30). At that time, according to this polemicist, Jesus should not have appeared to obscure people, but rather to authoritative, trustworthy, and respected people, contemporary with the resurrection itself, such as the Senate. His failure to appear to the Senators resulted in the impossibility for the Senate to verify his divine nature and, therefore, in a unanimous senatus consultum that condemned the Christians on the basis of an accusation of impiety:

"Why is it that Jesus, after his passion and resurrection - according to what you (Christians) recount - did not appear to Pilate, who had condemned him, even though he said that Jesus had committed nothing worthy of death penalty, or to Herod, the king of the Jews, or to the Jewish high priest or to many trustworthy ( $\alpha \xi$ ló $\pi \imath \sigma \tau \mathrm{\sigma})$ people, contemporary with the event (oi $\alpha \mu \alpha)$, and especially to the Senate and the people of Rome? In this way they would have been astonished by his miracles and would not have emitted, with a unanimo-

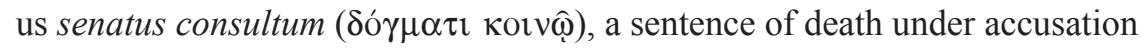
of impiety against his followers. [...] For, if he had manifested himself to no-

${ }^{69}$ Sancti Apollonii Romani Acta graeca, ed. in: Sancti Apollonii Romani Acta graeca: ex codice Parisino graeco 1219, AnBol 14 (1895) 13-14, 23-24, transl. by I.R.

${ }^{70}$ Eusebius Caesariensis, HE V 21, 4, ed. and transl. Lake - Oulton, I, p. 47-48.

${ }^{71}$ Ibidem V 21, 5, ed. and transl. Lake - Oulton, I, p. 47-48.

${ }^{72}$ Bibliography in Ramelli, Il senatoconsulto, p. 59-67; R. Goulet, Hypothèses récentes sur le traité de Porphyre Contre les chrétiens, in: Hellénisme et christianisme, éd. M. Narcy-É. Rebillard, Villeneuve d'Ascq 2004, 61-109.

${ }^{73}$ Cf. Macarius Magnes, Apocriticus 2, 14.

${ }^{74}$ Cf. R.M. Berchman, Porphyry against the Christians, Leiden 2005, 192-219 includes Macarius's passages as frr. $165-210$.

${ }^{75}$ On the identification of the pagan polemicist in Macarius's Apocriticus see at least E. DePalma Digeser, Porphyry, Julian, or Hierocles? The Anonymous Hellene in Makarios Magnes' Apokritikos, JTS 53 (2002) 466-502. 


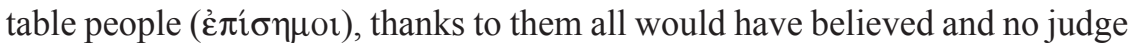
would have condemned them as inventors of absurd tales" $" 76$.

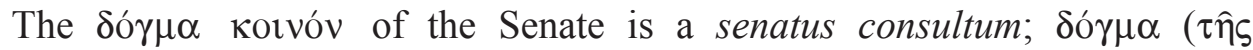

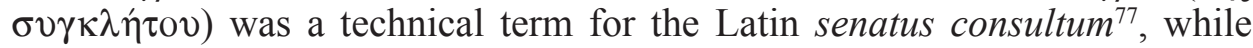
$\psi \eta \dot{\varphi} \sigma \mu \alpha$ indicated a decision of the people in assembly and $\delta \imath \alpha \tau \alpha \gamma \mu \alpha$ an edict of the emperor. This senatus consultum, according to Porphyry or the "pagan" polemicist of Macarius, accused of impiety and condemned to death the Christians shortly after the year 30. This corresponds to the senatus consultum of the age of Tiberius mentioned by Tertullian. The very expression that in this passage designates the senatus consultum corresponds to that used in

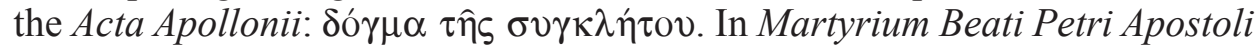
a Lino episcopo conscriptum, the Senators are depicted as those who most countered the Christians from the beginning: "Some of the Senators arose in the assembly of the Senate and exhorted the others, too, to confusion"78. This might be a faint echo of the senatus consultum of the year 35; at any rate it reflects the hostility of the Senate to Christianity from the beginning. Likewise, Origen's remark in Homiliae in Iesum Nave is too vague to be taken as a reference to the senatus consultum, but it is nevertheless interesting: "the kings of the earth have gathered together, the Senate and people and chiefs of Rome, to cancel the name of Jesus" "79. Indeed the senatus consultum did not allow Christians to exist qua tales, and endeavoured to suppress the nomen Christianum.

Shortly before Porphyry, Origen, whose works Porphyry knew and studied, in his Commentary on the Song of Songs had also observed that Jesus just after his resurrection did not appear to Pilate, Herod, or the high priests, because these lacked the spiritual capacity to discern his divinity. This responded to a criticism that was partially present in Celsus, whom Origen knew very well: Celsus blames Jesus for having appeared to a "hysterical woman" (that is, Mary Magdalene) ${ }^{80}$; later Lactantius reports "pagan” criticisms of Jesus for not manifesting himself in power ${ }^{81}$; Julian criticised Jesus for not performing miracles before Herod $^{82}$. The same criticism was also addressed by Tertullian, a contemporary of Origen: "Jesus (after his resurrection) did not appear to

\footnotetext{
${ }^{76}$ Porphyrius, Contra Christianos 64, ed. A. von Harnack: Porphyrius, Gegen die Christen, 15 Bücher: Zeugnisse, Fragmente und Referate, Berlin 1916, 85, transl. by I.R.

${ }^{77}$ Cf. Polybius, Historiae VI 13, 2; Dionysius Halicarnassensis, Antiquitates Romanae 8, 87.

${ }^{78}$ Martyrium Beati Petri Apostoli a Lino episcopo conscriptum 3, ed. R.A. Lipsius - M. Bonnet, in: Acta apostolorum apocrypha, Leipzig 1891, 4-5: "Surrexerunt quidam ex senatoribus in conventu senatus et [...] incitabant etiam alios ad tumultum", transl. by I.R.

${ }^{79}$ Origenes, In Iesum Nave hom. 9, 10, ed. A. Jaubert, SCh 71, Paris 1960, 268: "Convenerunt enim reges terrae, senatus, populusque et principes Romani, ut expugnent nomen Iesu", transl. by I.R.

${ }^{80}$ Idem, Contra Celsum II 59, ed. M. Marcovic: Origenes, Contra Celsum Libri VIII, Vigiliae

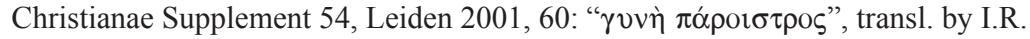

${ }^{81}$ Cf. Lactantius, Divinae Institutiones 4, 2.

${ }^{82}$ Cf. Julianus, Adversus Galilaeos fr. 104.
} 
everybody, that the impious may not be freed from their error, and that faith, which is destined to receive the most outstanding reward, might be achieved only with difficulty" 83 . Porphyry added to this lore the mention of "the Senate and the people of Rome" obviously because he wanted to introduce the theme of the condemnation of Christianity on the part of Rome, by means of the reference to the senatus consultum of the Tiberian age. It is not accidental that Porphyry, in his portrait of Origen in the third book of his writing against the Christians, deplored his adhesion to Christianity by saying that he lived "against the law" $(\pi \alpha \rho \alpha v o ́ \mu \omega \varsigma)^{84}$. This sounds like another echo of the senatus consultum that outlawed Christianity. It is not surprising that it comes, as is probable, from the same work as fr. 64 which refers to the senatus consultum rather clearly.

The author of fr. 64, be it Porphyry himself, as is likely, or a follower, cannot be suspected of Christian apologetical tendencies, unlike Tertullian. Therefore, his testimony concerning the senatus consultum is more difficult to dismiss than Tertullian's testimony.

Since it was Tiberius who, according to Tertullian, made the official proposal to the Senate, also putting in his favourable vote (cum praerogativa suffragii sui), the historian must ask how Tiberius could learn of Jesus and his followers who, by the year 35, only five years after Jesus' death and resurrection, were still mostly confined in Palestine. It is most likely that Pilate let his emperor know about the trial of Jesus - who was executed for maiestas ${ }^{85}$ as "king of the Jews" $(\mathrm{Jn} 19,19)$ - and his followers who were preaching his resurrection. The existence of this report is postulated, for instance, by Marta Sordi and Philippe Bourgeaud, who writes:

"It seems certain that Tiberius heard something about the death of Christ, that is, a man who was accused of presenting himself as a king, and whom some people deemed a god, and who was put to death in Judea under the mandate of the procurator Pilate; the latter, a magistrate elected by the emperor, must necessarily have been in touch with him. A tradition reported by Tertullian has it that Pilate sent to Tiberius a dossier about the religion of the Christians of Palestine, shortly after Christ's death (Eusebius dates this report to the year 35). Tacitus (Annales 15, 44) may have drawn his knowledge of the trial of Jesus from this official report" ${ }^{\prime \prime 6}$.

${ }^{83}$ Tertullianus, Apologeticum 21, 22, ed. Carpin, p. 252: "Nec se in vulgus eduxit, ne inpii errore liberarentur, ut et fides, non mediocri praemio destinata, difficultate constaret", transl. by I.R.

${ }^{84}$ Eusebius Caesariensis, HE VI 19, 4-8, ed. and transl. Lake - Oulton, I, p. 63-64.

${ }^{85}$ A common charge under Tiberius. See F.X. Ryan, Zum Majestätsverbrechen in den Bedürfnisanstalten unter Tiberius, "Gerión" 20 (2002) 413-415.

${ }^{86}$ P. Borgeaud, Exercices de mythologie, Genève 2004, 123-124: "il paraît certain que Tibère entendit parler de la mort du Christ, c'est-à-dire d'un homme accusé de se prétendre roi, et que certains considéraient comme un dieu, exécuté en Judée sous le mandat du procurateur Pilate; ce dernier, magistrat désigné par l'empereur, devait nécessairement se trouver en rapport avec lui. 
The arrival of this report in Italy was dated by Eusebius in his Chronicon exactly to the year 35 . Justin ${ }^{87}$ and Tertullian ${ }^{88}$ himself refer to this report, which must be kept distinct from the interpolated version handed down to us and from the false version that Maximinus Daia commissioned and that gave rise to the composition of apocryphal Acts of Pilate. The context of Justin's information suggests that Pilate's document narrated both Jesus's miracles and his execution, even with the detail of the soldiers's appropriation of his garment. Barnes remarks that the public records of Judaea were burnt in A.D. $66^{89}$. However, Pilate's report was not only kept in the archives in Palestine, but it was sent to Italy to Tiberius. This report is also mentioned in Evangelium Nicodemi ${ }^{90}$, Eusebius Historia Ecclesiastica ${ }^{91}$, and the Anaphora Pilati ${ }^{92}$. Tertullian is clear that Pilate informed Tiberius about Jesus: „He reported all this information concerning Christ to the emperor, who at that time was Tiberius" ${ }^{93}$.

Tiberius in the year 35 was in Capri. In the year 34 and earlier there had been the elimination of all those who had supported Seianus, who had been condemned and executed in the year $31^{94}$. It was feared that Tiberius might be killed during the meetings of the Senate and it was proposed to him to enter the Senate with a military escort ${ }^{95}$. Tiberius refused, which is easily understandable if one considers that, as Tacitus attests in Annales $^{96}$, Tiberius remained in Capri for six more years after the death of Seianus, until the year 37, that is, the year of Tiberius's own death. The business that resulted in the senatus consultum from the year 35 was conducted by the emperor in absentia, without entering the Senate in Rome.

Tertullian's account of the Tiberian senatus consultum was translated into Greek by Eusebius and from there, or from the Armenian version of Eusebius's Historia Ecclesiastica, was taken over by the Armenian historian Moses

\footnotetext{
Une tradition rapportée par Tertullien veut que Pilate ait envoyé à Tibère un dossier sur la religion des chrétiens de Palestine, peu après la mort du Christ (Eusèbe date cette relation de 35 ap. J.-C.). Il se peut que Tacite $($ Annales 15,44$)$ tire la connaissance qu'il a du procès du Christ de ce rapport officiel", transl. by I.R. Cf. Sordi, I cristiani e l'impero romano (second edition), p. 25-26.

${ }^{87}$ Cf. Justinus Martyr, Apologia I 35; 48.

${ }^{88} \mathrm{Cf}$. Tertulianus, Apologeticum 5, 2; 21, 24.

${ }^{89}$ Cf. Josephus Flavius, De bello Judaico 2, 427. See Barnes, Legislation against the Christians, p. 35 .

${ }^{90}$ Cf. Evangelium Nicodemi 29.

${ }^{91}$ Cf. Eusebius Caesariensis, HE II 1.

${ }^{92}$ Cf. The Report of Pontius Pilate, in: The Other Gospels: Accounts of Jesus from Outside the New Testament, ed. and transl. B.D. Ehrman - Z. Pleše, Oxford 2014, 267-271.

${ }^{93}$ Tertullianus, Apologeticum 21, 24, ed. Carpin, p. 254: “ea omnia super Christo [...] Caesari tum Tiberio nuntiavit", transl. by I.R.

${ }^{94}$ On Seianus cf. D. Hennig, L. Aelius Seianus: Untersuchungen zur Regierung des Tiberius, München 1975.

${ }^{95}$ Cf. Tacitus, Annales 6, 2.

${ }^{96} \mathrm{Cf}$. ibidem 4, 57.
} 
of Chorene ${ }^{97}$, a source that must always be treated critically but that does contain some reliable historical details unknown to other preserved sources ${ }^{98}$. To Tertullian's material Moses adds the letters exchanged by Tiberius and Abgar the Black, the toparch of Edessa, exactly in the years of the senatus consultum and of Lucius Vitellius's mission in the Near East. Moses in Historia Armeniae states that, during the conflict between Herod and Aretas, which ended in the years of Vitellius's mission in the Near East, Tiberius nominated a plenipotentiary with full control over Phoenicia, Palestine, Syria, and Mesopotamia, the territories controlled by Vitellius ${ }^{99}$. In the Paradosis Pilati Tiberius writes to "Lucian, the supreme ruler of the Eastern region", in order to punish the Jews responsible for the execution of Jesus and to process Pilate ${ }^{100}$. The very name Lucian corresponds to Lucius, Vitellius's name, and the content of the letter corresponds to that of the Abgar-Tiberius exchange and to what Vitellius actually did with the deposition of both Caiaphas and Pilate.

The letters reported by Moses are also found in the Syriac Doctrina Ad$d a i$ and are likely to have a historical nugget ${ }^{101}$. Here Abgar shows to know the basic facts concerning Jesus and his condemnation and points out that those responsible for the latter should be punished. Tiberius in his reply says that he has already deposed Pilate (a fact confirmed by Josephus in Antiquitates Iudaicae ${ }^{102}$ ) and will punish others responsible after settling the war that involved the Iberians ${ }^{103}$, a Caucasian people that Tiberius actually employed against the Parthians in the years of Vitellius's mission ${ }^{104}$. Indeed, Tiberius did depose Caiaphas as well through Vitellius ${ }^{105}$. The letters reflect the historical situation of A.D. 35-36, when Tiberius was engaging in political and military manoeuvres in the Near East against the Parthians, to which Vitellius's mis-

${ }^{97}$ Cf. Moses Chorenensis, Historia Armeniae 2, 33-36.

${ }^{98}$ As demonstrated by I. Ramelli, Un tributo dei Parti a Roma agli inizi del I sec. a.C.?, "Rendiconti dell'Istituto Lombardo, Accademia di Scienze e Lettere" 134 (2000) 321-330; eadem, Mosè di Corene e i rapporti Romano-partici. La spedizione di Ventidio, "Hispania Antiqua" 25 (2001) 141-155.

${ }^{99}$ Cf. Moses Chorenensis, Historia Armeniae 2, 30. See I. Ramelli, The Addai-Abgar Narrative: Its Development through Literary Genres and Religious Agendas, in: Early Christian and Jewish Narrative. The Role of Religion in Shaping Narrative Forms, ed. I. Ramelli - J. Perkins, Tübingen 2014 (in progress).

${ }^{100}$ Paradosis Pilati 6, transl. Ehrman - Pleše, in: The Other Gospels, p. 275.

${ }^{101}$ Cf. Ramelli, Possible Historical Traces, p. 1-78.

${ }^{102}$ Cf. Josephus Flavius, Antiquitates Judaicae 18, 4.

${ }^{103}$ Cf. I. Ramelli, The Possible Origin of the Abgar-Addai Legend: Abgar the Black and Emperor Tiberius, "Hugoye" 16 (2013) fasc. 2, 325-341.

${ }^{104}$ Cf. Tacitus, Annales 6, 32-33.

${ }^{105}$ Cf. I. Ramelli, Alcune osservazioni sulle origini del Cristianesimo nelle regioni ad est dell'Eufrate, in: La diffusione dell' eredità classica nell'età tardoantica e medioevale. Il Romanzo di Alessandro e altri scritti, Atti del Seminario Internazionale di Studi, Roma-Napoli 25-27 settembre 1997, ed. R.B. Finazzi - A. Valvo, Alessandria 1998, 209-225; eadem, Edessa e i Romani tra Augusto e i Severi: aspetti del regno di Abgar Ve di Abgar IX, “Aevum” 73 (1999) 107-143; eadem, Abgar Ukkama e Abgar il Grande alla luce di recenti apporti storiografici, “Aevum” 78 (2004) 103-108. 
sion was related ${ }^{106}$. The loyalty of kinglets of buffer states between Rome and the Parthians, such as Abgar's Osrhoene, was crucial to his policy. It is not accidental that Abgar in his letters repeatedly assured Tiberius of his faithfulness.

Abgar's letter to Tiberius was not prompted by his adhesion to Christianity (that he converted began to be stated only from Eusebius onward, or possibly from the early third century), but by political reasons. Abgar had good reasons to put those responsible for Jesus's death in a bad light before Tiberius. Abgar fought against Herod Antipas as an ally of Aretas, and both Pilate and Herod were hostile to Abgar and tried to discredit him before the Romans ${ }^{107}$. Caiaphas was an ally of Pilate and Herod Antipas; the latter's brother, Herod Agrippa, conferred the high priesthood on a son of Caiaphas. Pilate, a promoter of the imperial cult in Palestine, never deposed Caiaphas; they were allies and were deposed together in the year 36 by Vitellius by Tiberius's order. When Pilate sent Jesus to Herod - because as a Galilaean he belonged to Herod's jurisdiction - and Herod sent Jesus back to Pilate, Herod and Pilate became friends (Lk 23, 12). As a consequence, the Jesus business was a good occasion for Abgar to attack both Pilate and Herod, as well as their ally Caiaphas, discrediting them before Tiberius as responsible for an unjust execution.

These arguments support the historicity of Tertullian's account concerning the senatus consultum of the year 35, which, by rendering Christianity a superstitio illicita, provided a juridical basis for persecutions from Nero onward. Nero was the first who removed Tiberius's veto and thus made the decision of the Senate effective. This is why Tertullian called him "the initiator of our condemnation" (dedicator damnationis nostrae) $)^{108}$ and spoke of "Nero's inauguration" of the persecutions against Christians" (institutum Neronianum) ${ }^{109}$. In the same passage he makes it clear that the condemnation of Christians "began to have validity and course" (invaluit), and not simply to exist, under Nero: "Under the principate of Augustus the Christian name appeared, under Tiberius its teaching shone forth, and under Nero its condemnation began to have validity and course" 110 . For it had existed since the year 35 , but the condemnation of Christians merely as Christians, which Tiberius's intervention had suspended, began to be applied after the year 62, i.e. after Nero's U-turn. Precisely because it existed already before Nero, the illegality of Christianity remained even after Nero's death and damnatio memoriae, when all of his other decisions were abolished (as Tertullian puts it, Tamen permansit erasis omnibus hoc solum institutum Neronianum). The illegality of the Christians remained, because it was not decided by Nero, but by the Senate long before Nero.

\footnotetext{
${ }^{106}$ Cf. Tacitus, Annales 6, 31-37 and 41-44.

${ }^{107}$ Cf. Moses Chorenensis, Historia Armeniae 2, 39.

${ }^{108}$ Tertulianus, Apologeticum 5, 3-4, ed. Carpin, s. 138-140, transl. by I.R.

${ }^{109}$ Idem, Ad nationes I 7, 9, ed. W.Ph. Borleffs, CCL 1, Turnhout 1954, 68, transl. by I.R.

${ }^{110}$ Ibidem I 7, 8, CCL 1, 68: "Principe Augusto nomen hoc ortum est, Tiberio disciplina eius inluxit, Nerone damnatio invaluit", transl. by I.R.
} 
KONSTANTYN I PRAWNA LEGALIZACJA CHRZEŚCIJAŃSTWA: ZMIANY KONSTANTYNA I JEGO PREKURSORZY

(Streszczenie)

Cesarz Konstantyn nie tylko zdecydowanie zniósł skutki senatus consultum z roku 35, zakazującego wyznawania chrześcijaństwa, lecz także przekształcił je w Imperium Rzymskim z illicita superstitio w religio licita. Jednak już przed Konstantynem były takie próby - usiłował to dokonać Galien, jednak tylko z efektem częściowym i czasowym; być może zamierzali uczynić to także Hadrian, Aleksander Sewer i Heliogabal, jednak bez powodzenia. Najbardziej niezwykłą, chociaż problematyczną, relację do chrześcijaństwa miał Tyberiusz. W niniejszym artykule przeanalizowano źródła oraz znaczenie lekceważonego zazwyczaj senatus consultum z roku 35, które jest potwierdzone nie tylko u Tertuliana, ale także u Porfiriusza i w Aktach Apoloniusza, Senatora i Męczennika.

Key words: Constantine, senatus consultum, Christianity.

Słowa kluczowe: Konstantyn, senatus consultum, chrześcijaństwo. 